\title{
Tempo de deserto: literatura e engajamento em Claraboia, de José Saramago
}

\author{
Tempo de deserto: literature and commitment in José Saramago's Claraboia
}

\author{
GREGÓRIO FOGANHOLI DANTAS \\ Universidade Federal da Grande Dourados - Dourados - Mato Grosso do Sul - Brasil
}

-

\begin{abstract}
Resumo: O romance póstumo de José Saramago, Claraboia (2011), foi escrito no início dos anos 50, ainda sob a forte influência do neorrealismo. O romance apresenta semelhanças temáticas e formais com obras neorrealistas, como Suor, de Jorge Amado, e Casa da malta, de Fernando Namora. Seus personagens são párias sociais, pessoas recolhidas em um espaço degradado, vivendo em condições desumanas. Claraboia descreve o lento processo de tomada de consciência social, que separa o intelectual engajado e comprometido com seu momento histórico, do homem alienado e alijado de seus básicos direitos. Deste modo, o herói de Claraboia antecipa o personagem H., de Manual de pintura e caligrafia (1977).
\end{abstract}

Palavras-chave: José Saramago; Romance português; Neorrealismo

\begin{abstract}
The José Saramago's posthumous novel, Claraboia (2011), was written in the early ' $50 \mathrm{~s}$, still under the strong influence of neorealism. The novel presents formal and thematic similarities with novels of neorealism, as Jorge Amados's Suor and Fernando Namora's Casa da malta. Its characters are social outcasts, people gathered in a degraded area, living in inhumane conditions. Claraboia describes the slow process of social awareness, which separates the intellectual engaged and committed to their historical moment, from the alienated man, alienated from their basic rights. Thus, the hero of Claraboia anticipates the character H., of Manual de pintura e caligrafia (1977)
\end{abstract}

Keywords: José Saramago; Portuguese novel; Neorealism

O caso se tornou célebre na biografia de José Saramago. Em 1953, o manuscrito de seu romance Claraboia foi submetido à publicação. A editora, porém, além de não enviar qualquer resposta ao autor, não lhe devolveu o manuscrito, dado como perdido até meados dos anos 80; nessa época, já escritor renomado, Saramago foi notificado de que o manuscrito perdido havia sido encontrado, e recebeu a proposta de publicação do romance. Talvez ressentido, talvez apenas ciente de que o romance pouco acrescentaria a sua já sólida carreira, Saramago recusou o convite, e deixou a cargo de seus herdeiros o destino do livro. Seu lançamento póstumo já era, portanto, aguardado.

Claraboia é o segundo romance de Saramago; a tentativa anterior não fora bem-sucedida. Terra do pecado, publicado em 1947, era um romance bastante calcado na estética naturalista, com ecos evidentes de $O$ primo Basílio. Assim como Luísa, a protagonista de Saramago, Maria Leonor é chantageada pela empregada da família sob a suspeita de traição à memória do marido defunto, ao apaixonar-se pelo cunhado. O título do romance, sugerido pela editora - o título original seria $A$ viúva - evidencia o tom moralista da obra.

Em seu capital estudo sobre o "período formativo" da obra de José Saramago, Horácio Costa atenta para o anacronismo de Terra do pecado. Em um período em que seus contemporâneos, influenciados sobretudo pelo romance de 30 brasileiro, alcançavam uma "dicção explosivamente nova, em termos de uma releitura da vertente de consciência social que de modo crescente se fora imprimindo na literatura portuguesa desde o realismo", ou seja, promoviam a "superação e renovação" do naturalismo oitocentista (COSTA, 1997, p. 28), Saramago ainda se atinha aos velhos modelos, postura notável não apenas na adoção explícita do vocabulário naturalista, e da discussão de alguns de seus expoentes teóricos (como Spencer), mas sobretudo no conflito de sua protagonista, consciente da abjeta submissão aos seus instintos bestiais. O consolo de Maria Leonor é saber-se fêmea e, como qualquer outra, ser vítima de um desejo incontornável. 
Quero sentir-me ínfima, idêntica à primeira fêmea irracional que atraiçoa pela primeira vez o macho preferido, já depois dele morto... (...) Tudo isso é simples e claro, duma simplicidade e duma clareza naturais... Uma mulher, um homem, a chispa que salta, a razão que se encadeia, e é tudo... Quando sucedeu, achei-me reles (...) Depois, acalmei-me, concluí que não agira propriamente como mulher (...) eu procedera como a fêmea pré-histórica que se embrenhava no mato, berrando, ciosa pelo macho, e que se espojava depois na terra fecunda e negra. Eu era joguete das forças naturais do sexo, as mais misteriosas forças da vida, que são o anseio íntimo para a imortalidade dos deuses. Foi pensando nisso que me acalmei. (Apud COSTA, 1997, p. 33)

O romance Terra do pecado não recebeu acolhida significativa, seja por parte do público, seja por parte da crítica. De qualquer modo, a publicação animou o autor. O biógrafo José Marques Lopes relata que, entre 1947 e 1953, Saramago teria escrito, além dos poemas e peças de teatro, uma série de contos publicados na imprensa, diversos textos que permaneceram inacabados e o romance Claraboia.

Como o romance anterior, trata-se de uma narrativa de corte bastante conservador, ainda distante do estilo que caracterizaria a obra de Saramago nos anos 80. Não apenas devido ao respeito à pontuação tradicional e aos diálogos convencionais, mas também a certo didatismo na apresentação dos personagens e na condução do enredo.

O capítulo inicial de Claraboia nos ambienta em um prédio bastante modesto, habitado por seis famílias. Como em um travelling cinematográfico (um planosequência que desafiaria o cineasta mais arrojado), adentramos seus apartamentos e conhecemos suas vidas: o sapateiro Silvestre, em busca de um inquilino para ajudar nas despesas; a abatida Justina, em luto desde a morte da filha, e às voltas com as traições do marido; a romântica Isaura, leitora de romances que a mãe certamente não recomendaria, se os conhecesse; a espanhola Carmen, envolvida com a saúde frágil do filho e uma relação autodestrutiva com o marido; a bela Lídia, que recebe regularmente o amante que a mantém, e habita os devaneios dos homens da vizinhança; a jovem Maria Cláudia, admiradora e futura rival de Lídia, motivo de apreensão dos pais.

Cada um dos capítulos seguintes é dedicado a um dos núcleos familiares, raramente saindo dos limites do prédio, dos pequenos apartamentos onde "o tempo deslizava, continuamente, com aquele rumor sedoso que tem a areia correndo na ampulheta" (SARAMAGO, 2011, p. 73). Através do amplo uso dos diálogos e do discurso indireto livre, o narrador onisciente nada esconde; não há lugares de sombra, de indefinição, seja na composição dos personagens, seja nos conflitos estabelecidos: a esposa insatisfeita, a jovem romântica, o marido infiel.

A metáfora é clara: o prédio como um microcosmo que representa as condições da parte desfavorecida da população portuguesa. Uma população em luta para manter-se financeiramente, sem perspectivas de ascensão social e, principalmente, impedida do exercício de qualquer prazer ou realização pessoal, a não ser o exercício diário da mesma rotina, sob o jugo das mesmas amarras sociais, econômicas e morais.

A voz mais autoral de Saramago, responsável por aquele estilo narrativo consagrado a partir de Levantado do chão, não se faz ouvir senão em raros momentos, quando o narrador entrega-se a um ou outro comentário que, se não chega a constituir uma de suas digressões mais espirituosas, já demonstra certa vocação para dizer o óbvio, o supérfluo, "pelo simples gosto de escrever as palavras e dizê-las de modo saboroso" (SARAMAGO, 2002, p. 73). Como o insólito comentário sobre uma expressão idiomática: "um estrangeiro desconhecedor das expressões idiomáticas portuguesas e entendendo à letra tudo o que ouvisse dizer, julgaria estar numa casa de loucos (...)" (SARAMAGO, 2011, p. 240). Mas se trata de um comentário excepcional: o narrador logo recupera a linearidade do enredo e dos personagens, e permanece preso à forma do romance mais convencional.

Se Terra do pecado era ainda totalmente tributário dos imperativos naturalistas, Claraboia representa um passo adiante, mais próximo da voga neorrealista de que é contemporânea. Mais especificamente, há duas obras com as quais Claraboia se alinha claramente: Suor (1934), de Jorge Amado, e A casa da malta (1945), de Fernando Namora. Tal aproximação justifica-se pela reconhecida proximidade entre a chamada literatura de 30 no Brasil e o romance neorrealista português dos anos 40. Autores e obras compartilham o mesmo "ecossistema literário", conceito cunhado por Benjamim Abdala Jr.:

Quando comparamos literaturas de um mesmo sistema linguístico, modelos semelhantes de articulação literária tendem a ser utilizados com maior frequência pelas similaridades dos discursos ideológicos e de outras séries culturais. (...) Pela proximidade da situação comunicativa, conforme temos desenvolvido, a tendência é africanos lusófonos, brasileiros e portugueses trabalharem literariamente modelos geradores equivalentes, com 'estratégias' discursivas igualmente confluentes. (ABDALA JR., 2007, p. 65)

Seguramente, a influência notável que escritores como Graciliano Ramos, Jorge Amado e José Lins do Rego exerceram sobre a obra de Alves Redol, Soeiro Pereira Gomes, Fernando Namora e Carlos de Oliveira, é um 
claro exemplo das "estratégias discursivas confluentes" de que fala Abdala Jr.

Em um importante estudo sobre essa relação de influência, Edvaldo Bergamo (2008) demonstra como a primeira geração do neorrealismo português incorporou muito do projeto estético-ideológico de Jorge Amado, o que contribuiu "decisivamente para o surgimento de um novo romance social em Portugal" (BERGAMO, 2008, p. 20). Para demonstrá-lo, o ensaísta estabelece pares comparativos entre os romances de Jorge Amado e as obras portuguesas que com eles dialogam; deste modo, Suor e A casa da malta compartilham algumas características fundamentais, como a reprodução de um espaço degradado em que vivem personagens miseráveis, párias sociais ou trabalhadores submetidos aos imperativos de injustas relações de trabalho.

Suor (1934) é o terceiro romance de Jorge Amado, ainda pertencente à fase que o próprio autor definiu como sendo a dos "cadernos de aprendiz de romancista" (apud DUARTE, 1996, p. 37), em que exercitava temas e tipos. O tom é claramente de denúncia das mazelas sociais que assolavam o país. Cacau, de 1933, que já era moldado pela cartilha do romance proletário, guardava o objetivo de contar, "com o mínimo de literatura pra um máximo de honestidade, a vida dos trabalhadores das fazendas de cacau do sul da Bahia", conforme a nota que abre o romance (AMADO, 1971, p. 101). "Literatura", nesse contexto, deve ser entendida em sentido pejorativo, como "literatice", de modo que Amado pretendia alcançar uma linguagem que não se perdesse em frivolidades das modas literárias, mas mostrar a verdade da vida daqueles trabalhadores. Apesar disso, e como bem demonstra Eduardo de Assis Duarte (1996), a nota estigmatizou o autor e serviu aos seus detratores, que localizaram na declaração o maior defeito do romance: sua "pouca literatura", no sentido de baixa qualidade literária. E eles não estão errados, como provam os personagens estereotipados e o esquematismo de certos conflitos do romance, muito adequados ao tom de cartilha política. É estabelecido, sobretudo, um tipo recorrente na ficção amadiana, a do herói excluído e oprimido pela sociedade, em processo de aprendizagem e de amadurecimento, adquirindo consciência de classe. Ao final do romance, de maneira inverossímil, mas consistente com o tom didático do livro, o protagonista sacrifica seus sentimentos em nome de um bem maior, o da sua classe: "O amor pela minha classe, pelos trabalhadores e operários, amor humano e grande, mataria o amor mesquinho pela filha do patrão. (...) Eu partia para a luta de coração limpo e feliz" (AMADO, 1971, p. 169). O tema do herói em processo de aprendizagem irá se manter em todos os seus romances da década de 30, chamados pelo próprio autor de "Romances da Bahia": como Jubiabá, Mar morto e Capitães da areia.
Em Suor, Amado nos conta a história de um sobrado onde vive um grupo bastante heterogêneo de pessoas, unidas pelas circunstâncias e pela miséria. São trabalhadores, mendigos, prostitutas, toda a classe de excluídos pela exploração capitalista, vivendo provisoriamente em um espaço exíguo, cuja degradação física reflete a degradação moral e social daqueles personagens: "um mundo fétido, sem higiene e sem moral, com ratos, palavrões e gente" (AMADO, 2011, p. 10).

Segundo Bergamo (2008), a degradação do espaço físico reflete-se em outros dois níveis: no texto e nos personagens. Como um mosaico, a narrativa é composta por fragmentos, cenas daquelas vidas infelizes sobrepostas de maneira aparentemente aleatória. Sucedem-se personagens esquemáticos, algo estereotipados, como o agitador político, responsável pelas palavras de ordem, e a jovem Linda, que abandona a frivolidade dos folhetins para compreender os determinantes históricos e sociais a que está submetida para se emancipar e se engajar politicamente. Há ainda o mendigo Cabaça, cujas condições precárias de vida escodem uma consciência de classe formada por anos de trabalho explorado. Ex-operário mutilado pelo trabalho, vivendo no canto mais infecto do cortiço, Cabaça lê o jornal antes de se enrolar nele e dormir sobre a urina de ratos e homens.

Há, portanto, alguma esperança, mesmo na mais abjeta das condições. A tomada de consciência social passa pela percepção do funcionamento da máquina capitalista, e do estabelecimento, por parte dos personagens, mas com a total simpatia do narrador (e, espera-se, do leitor), de um discurso de ordem e de proposta de ação:

Álvaro Lima se levantou e falou:

- Camaradas! É preciso acabar com as explorações. Nós somos muitos, pobres, sujos, sem comida, sem casa, morando nesses quartos miseráveis. Explorados pelos ricos, que são poucos... É preciso que todos nós nos unamos, para nos defender... Para a revolução dos operários. É preciso que os operários se juntem em torno do seu partido, para acabar com as explorações... com os governos podres e ladrões... Fazer um governo de operários e camponeses... (AMADO, 2011, p. 62)

O discurso de emancipação política, ainda que legítimo, não escapa do maniqueísmo: à pergunta perplexa de uma criança - "Quem matou papai?" -, a resposta do adulto não poderia ser mais simplista: "Os ricos..." (AMADO, 2011, p. 62-63). Como a mensagem final do livro, que não poderia ser mais clara: "A escada era a única coisa que ligava os inquilinos... Hoje há outra, a solidariedade que nós despertamos" (AMADO, 2011, p. 129). 
Suor, como os "romances da Bahia", emite a mensagem necessária para uma época marcada pela emergência e pela consolidação dos regimes totalitários. Em Portugal, a reação ao salazarismo exigia uma literatura de combate político imediato, que abandonasse o esteticismo da geração da Presença e se voltasse para as agruras e as injustiças sociais. E a literatura brasileira da década de 30 trazia o conteúdo humanístico necessário à ação (não à toa, Jorge Amado e seus contemporâneos teriam mais tarde um alcance ainda maior, na África de língua portuguesa). Alves Redol, entusiasmado com o que havia de "verdade" naquela nova literatura brasileira, incitava seus conterrâneos a descobri-la:

Das caatingas, dos cais, das fábricas, do bulício das cidades, da quietude dos sertões, recolheram todo o seu vasto material humano, pondo-o a viver nas suas obras, emotivando-nos com os seus sonhos e os seus desesperos, cumprindo, assim, a mais alta missão da arte - a socialização dos sentimentos. (Apud BERGAMO, 2008, p. 85)

Afim à missão realista e denunciadora desses romances, era patente um tom otimista, de que era possível ao trabalhador a emancipação política, somado a um estilo a que Adolfo Casais Monteiro definiu como "realismo lírico", que trabalhava o:

Contraste da aspereza da vida cotidiana dos homens lutando pelo pão e pela felicidade com a melodia interior, com o cântico de saudade e de esperança misturadas que na alma de todos os homens vibra initerruptamente. (Apud BERGAMO, 2008, p. 100).

Neste contexto, A casa da malta, de Fernando Namora, repete a premissa de Suor: trata de um grupo de pessoas - mendigos, imigrantes, ciganos - vivendo sob um mesmo teto, dessa vez um prédio abandonado que já fora usado como abrigo de porcos. As condições são desumanas, e a degradação física, mais uma vez, reflete a decadência moral dos miseráveis:

Um dia aparecera por ali uma mulher estragada, das da vida, e uma semana depois davam com ela morta e podre num canto do saguão. Foi enterrada quando os bichos comiam a sua carne lívida e desfeita em água ludra; a autoridade foi contar que as palhas tinham sangue dos seus pulmões, e toda a casa um cheiro empestado. Ficou o saguão com a fama de um lugar de nojo, maldito e sem dono. Agora é dos malteses: vagabundos, ciganos, gente do mundo que não escolhe tecto. É a casa da malta. (NAMORA, 1998, p. 52)

Mas há também, como convém, a figura que congrega a possibilidade de emancipação política: o velho Troupas é um personagem maduro, chamado de "mendigo filósofo", que compreende os "meandros da espoliação econômica, por isso não é ingênuo e apresenta certa sagacidade" (BERGAMO, 2008, p. 149). Sob o discurso da solidariedade possível, a casa da malta adquire o status de um lugar de "conforto espiritual", em que os desafortunados e miseráveis se protegem dos de fora, da vida hostil, numa "espécie de trincheira simbólica contra uma ordem social segregadora e injusta" (BERGAMO, 2008, p. 148). Igualmente simbólico é o parto da cigana, cujo impudor "fazia-os ainda mais chegados, numa grande família. Família! Uma família que se prolongava ainda para lá das quatro paredes do saguão, tão grande que nela cabiam todos os corações do mundo" (NAMORA, 1998, p. 90).

É precisamente a possibilidade de solidariedade o que distingue Namora e Amado dos naturalistas. Em ambos os romances, o cortiço é um espaço de exceção, o lugar em que excluídos e miseráveis se escondem, por assim dizer, das agruras sociais; para além do estudo fisiológico desses seres, o escritor se propõe a compreender os determinantes que os levaram àquela condição, preocupação exemplar da mudança de enfoque do neorrealismo em relação ao naturalismo, na medida em que "a noção de luta de classes substitui o fatalismo determinista" (DUARTE, 1997, p. 66). A orientação deixa de ser cientificista no sentido biológico, e passa a ser marxista, histórica.

Quando Claraboia foi escrito, a primeira fase do neorrealismo - a fase dita heroica, de combate político mais evidente - já estava no fim. Ainda assim, o romance compartilha algumas semelhanças inegáveis com os livros de Amado e Namora. A começar pela premissa inicial, a das vidas que se reúnem sob o mesmo teto, como um microcosmo que representa certa parcela da sociedade, premissa, aliás, herdada dos naturalistas $-O$ cortiço, $L$ 'assomoir - e desdobrada em uma familiar rede de temas e motivos ${ }^{1}$. São também comuns aos três romances o esquematismo dos personagens e certo didatismo por parte do narrador. Quando Silvestre, por exemplo, tem a fugaz ilusão de que poderia estar sendo vigiado, o narrador usa ostensivamente o mesmo procedimento - as reticências para insinuar o óbvio, uma vida pregressa politicamente ativa de Silvestre: "Não tinha nada a recear, nunca fora incomodado desde que... desde que deixara aquelas coisas e agora já estava velho" (SARAMAGO, 2011, p. 66-67). A repetição das reticências, ao referir-se logo em seguida a "acontecimentos remotos do tempo em que..." (SARAMAGO, 2011, p. 67) reafirmam seu didatismo.

\footnotetext{
Saramago revisita, por exemplo, nos personagens de Justina e seu marido, a célebre cena de $O$ cortiço (1890), em que o português Miranda possui a esposa durante o sono: apesar do ódio recíproco, ele cede aos apelos da carne "com delírio, com verdadeira satisfação de animal no cio", ato "que a ambos acanalhava aos olhos um do outro" (AZEVEDO, 2012, p. 74).
} 
Formalmente, há sobretudo a fragmentação do enredo em capítulos destinados, cada qual, a um núcleo familiar. Contudo, sugere-se entre as cenas uma continuidade nada gratuita, movimento desenvolvido em sua plenitude ainda no primeiro capítulo, mas ligando ocasionalmente essas diferentes vidas. Assim, o som que assombra os sonhos de Justina no final de um capítulo mostra-se, na verdade, o movimento de uma sinfonia de Beethoven, à qual a família de Adriana ouve atenta. Ou o silêncio que vela a vigília noturna de Justina é quebrado, no início do capítulo seguinte, pelas vozes dos vizinhos que voltam do cinema, e cujos passos repercutem por todo o prédio.

É importante destacar ainda uma diferença significativa de Claraboia em relação a Suor e Casa da malta: a degradação dos personagens, em Saramago, não é tão ostensivamente física quanto nesses romances. Não há escatologia. E mesmo a demonstração de lascívia, fruto de um determinismo de pendor francamente naturalista, é bastante discreta se comparada à de seus contemporâneos.

Em Claraboia, predomina a degradação no plano simbólico. No cotidiano daquelas famílias delineiam-se traços de desumanização, promovidos sobretudo pela impossibilidade de realização do desejo, não apenas físico, mas espiritual, artístico, afetivo.

Ali, em casa, não havia miséria, e a mesa tinha comida em todas as refeições, mas havia a rigidez do orçamento apertado, donde fora excluído todo o supérfluo, até aquele supérfluo necessário sem o qual a vida do homem se processa quase ao nível da dos animais (SARAMAGO, 2011, p. 45-46).

O supérfluo: para a família da jovem Adriana, atenta aos números musicais do rádio, é uma sinfonia de Beethoven; para o sapateiro Silvestre, o jogo de damas com o jovem inquilino; para a família de Maria Cláudia, são os cinco minutos dedicados ao chá, motivo de uma satisfação íntima, "como se de repente tivessem deixado a mediocridade da sua vida para subir uns furos na escala do bem-estar econômico" (SARAMAGO, 2011, p. 53). E sobre todas as coisas impera a lenta passagem do tempo, visível nas rugas da cortesã que se vê prestes a se aposentar, ou na inércia das senhoras que abandonaram há muito a esperança: "Duas mulheres velhas e duas que já voltavam costas à mocidade. $\mathrm{O}$ passado para recordar, o presente para viver, o futuro para recear" (SARAMAGO, 2011, p. 47).

Nesses termos, a vida torna-se mais introspectiva. O tempo se arrasta, claustrofóbico. Em particular, no apartamento fantasmagórico de Justina - expressão mais evidente de um estado de "morte em vida" - onde se impõe, "para aquém - ou talvez para além - dos rumores inevitáveis, um silêncio espesso, confrangedor, o silêncio inquisitorial do passado que nos contempla e o silêncio do futuro que nos espera" (SARAMAGO, 2011, p. 86). O tempo é suspenso:

O tempo fluía lentamente. O tique-taque do relógio empurrava o silêncio, insistia em querer afastá-lo, mas o silêncio opunha-lhe a sua massa espessa e pesada, onde todos os sons se afogavam. Sem desfalecimento, um e outro lutavam, o som com a obstinação do desespero e a certeza da morte, o silêncio com o desdém da eternidade. (SARAMAGO, 2011, p. 37)

O silêncio é também metonímia para a incomunicabilidade:

Por isso, entre ambos, o silêncio era a regra e a palavra a exceção. Por isso, nada mais que sentimentos gelados e olhos distantes preenchiam o vácuo das horas passadas em comum. E o cheiro a bafio que inundava a casa, aquela atmosfera de subterrâneo, era como o cheiro dos túmulos abandonados. (SARAMAGO, 2011, p. 163)

$\mathrm{Na}$ ausência de eventos ou coisas que confiram sentido àquelas vidas, humanizando-as ${ }^{2}$, os personagens terminam por se esconder em sua interioridade. Justina "vivia dentro de si mesma, como se estivesse sonhando um sonho sem princípio nem fim, um sonho sem assunto de que não queria acordar, um sonho todo feito de nuvens que passavam silenciosas encobrindo um céu de que já se esquecera" (SARAMAGO, 2011, p. 97). Já Isaura mal esconde "aquele frêmito que se adivinhava sob a pele e que denunciava uma vida interior intensa e tumultuosa" (SARAMAGO, 2011, p. 221). E, ciente da incontornável incomunicabilidade entre as pessoas, o pai discursa ao filho recém-nascido: "Não sabes quem eu sou e nunca saberás. Ninguém sabe... Também não sei quem és. Não nos conhecemos... Podia ir-me embora, que só perderias o pão que ganho" (SARAMAGO, 2011, p. 104).

Deste estado de impossibilidade do desejo, de incomunicabilidade, avultam momentos de lúbrico alívio. A sensualidade insinua-se nas frinchas do cotidiano, seja triste e violenta em Justina, insinuante na jovem Maria Cláudia, algo melancólica no banho de Lídia, perturbadora e conflituosa em Isaura, numa "agitação dos instintos que quebravam algemas e irrompiam na carne" (SARAMAGO, 2011, p. 170). Porém, se o tema dos

\footnotetext{
Nesse ponto, vale recorrer à célebre distinção utilizada por Antonio Candido no seu "Direito à literatura": citando o sociólogo francês Luis-Joseph Lebret, Candido diferencia os chamados direitos "incompressíveis", ou seja, "direitos que não podem ser negados a ninguém (...), como o alimento, a casa, a roupa", dos considerados bens "compressíveis", ou seja, supostamente supérfluos à vida cotidiana (CANDIDO, 2004, p. 173)
} 
impulsos fisiológicos é afim ao naturalismo de cartilha - como em Terra do pecado -, Claraboia alinha-se ideologicamente aos romances neorrealistas, nos quais se indica uma possibilidade de redenção, através da tomada de consciência social.

Abel, inicialmente, é um jovem individualista, que vive de emprego em emprego, às vezes passando fome, mas sempre exercendo seu direito de liberdade e de solidão. "Quando me sinto agarrado, corto o tentáculo..." (SARAMAGO, 2011, p. 192), diz ao sapateiro Silvestre.É precisamente a amizade com esse senhor que o influencia a ponto de promover uma mudança essencial; a amizade com um senhor cujo sereno estado de felicidade, em pleno exercício de um amor tranquilo e confortável com sua velha esposa (isso a despeito de sua precária situação financeira) deixa o jovem Abel perplexo.

Que é que dava à pobreza dos seus hospedeiros aquele som de metal puro? (...) 'Talvez a compreensão... Mas a compreensão é uma palavra, apenas. Ninguém pode compreender outrem, se não for esse outrem. E ninguém pode ser, ao mesmo tempo, outrem de si mesmo (...) Estará na natureza de certas pessoas esta capacidade de se desprender de si mesmas algo que transfigura a vida? Algo, algo... Algo, pode ser tudo ou quase nada. O que interessa é saber o quê. Mas, então, vejamos, ponhamos a pergunta: o quê? (...) Que pessoas são essas? Que capacidade é essa? Em que consiste a transfiguração? Não estarão estas palavras demasiado longe do que querem exprimir? A circunstância de ser forçoso o uso das palavras não dificultará a resposta? Mas, nesse caso, como achá-la?' (SARAMAGO, 2011, p. 187-188)

Delineia-se um tema que se tornaria recorrente em Saramago, o da incomunicabilidade, visível em pelo menos dois níveis. Um, essencial: na medida em que se é impossível ser outro, é impossível conhecer o outro em sua intimidade; a consciência dessa cisão fundamental funda, de certo modo, o sentimento de alteridade. Há ainda um nível a que poderíamos chamar de instrumental: a palavra, não sendo a coisa, não pode representá-la senão em termos muito pobres, "porque elas não são, as palavras, aquilo que declaram" (SARAMAGO, 2006, p. 199-200). A consideração é do narrador de $O$ ano da morte de Ricardo Reis, a partir de uma reflexão do heterônimo pessoano, um dos muitos personagens do autor que se defrontarão com a impotência da palavra frente ao mundo. Abel indaga: se o mundo e os sentimentos não são passíveis de representação (literária, inclusive), como se referir a eles, e como refletir sobre a condição humana? A essas questões, sobrepõe-se um sentimento aniquilador de tédio, de imobilidade, semelhante ao que paira sobre as famílias do prédio. Nada disso é novo, e Abel logo o reconhece:
Nem sequer o que penso tem o mérito da originalidade. É como um fato em segunda mão num estabelecimento de obra nova. É como uma mercadoria fora do mercado, embrulhada em papel colorido com um nastro de cor a condizer. Tédio e nada mais. Cansaço de viver, arroto de digestão difícil, náusea. (SARAMAGO, 2011, p. 255)

Ao contrário dos outros moradores, porém, Abel finalmente consegue, se não formular uma reflexão detalhada sobre sua situação, ou um plano de ação, ao menos enunciar a questão em termos éticos. Vem de Silvestre a indicação de sua responsabilidade. No capítulo XXI, o sapateiro tenta explicar ao jovem que há diferentes maneiras de se manter os olhos abertos. Pode-se estar vivo, pode-se ver as coisas, sem no entanto vê-las de fato, enxergá-las como elas são. Render-se aos tentáculos da vida não significa entregar-se ao marasmo mesquinho da vida pequeno-burguesa, mas comprometerse. Este diálogo, por demais evidente, sem sombras ou subentendidos, é aliás um bom indicador do didatismo - formal e ideológico - indicado anteriormente, e que permeia todo o processo de tomada de consciência de Abel - através, principalmente, do discurso indireto livre.

Algumas vezes, desde que começara a viver livremente, Abel perguntara a si mesmo: 'Para quê?'. A resposta era sempre igual e também a mais cómoda: 'Para nada'. E se o pensamento insistia: 'Não é nada. Assim não vale a pena', acrescentava: 'Deixo-me ir. Isto há de ir dar a algum lado'.

Bem via que 'isto', a sua vida, não ia dar a parte alguma, que procedia como os avarentos que amontoam o ouro só para terem o prazer de o contemplar. No seu caso não se tratava de ouro, mas de experiência, único proveito da sua vida. Contudo, a experiência, não sendo aplicada, é como o ouro imobilizado: não produz, não rende, é inútil. E de nada vale a um homem acumular experiência como se colecionasse selos. (SARAMAGO, 2011, p. 249)

Neste sentido, a simples afirmação ética já é algo positiva, uma forma incipiente de resistência à passividade do sujeito alienado, que se desdobra em outras questões: a necessidade de Abel em tornar-se uma pessoa "fútil e tributável", para usar a expressão de Fernando Pessoa em "Tabacaria"; sua suposta originalidade de pensamento, que o distingue do "comum das gentes"; a dúvida quanto aos meios e aos instrumentos de intervenção; o ceticismo quanto à própria validade de uma intervenção - o que, segundo the mostra a experiência, é sempre inútil. Abel é um cético e um pessimista. Mas a própria enunciação dessas questões, ainda que insegura, é já um indício de engajamento.

Por isso, a conversa final entre Abel e Silvestre a despeito de certa pieguice e, mais uma vez, de um empenhado didatismo - é bastante representativa de um 
conflito que acompanhará o narrador de José Saramago em muitos dos livros que viriam depois: "A vida é uma luta de feras, a todas as horas e em todos os lugares (...). O amor é o pregão dos fracos, o ódio é a arma dos fortes" (SARAMAGO, 2011, p. 369), diz o cético Abel. Ao que Silvestre reage, defendendo entusiasticamente o amor fraterno e possível entre todos os homens. É entre o pessimismo de um e a utopia do outro que Saramago irá estabelecer certa dialética de um engajamento possível em seus romances. Ainda estamos longe da noção de coletividade perpetrada em Levantado do chão (1980) ou da revisão crítica da História a partir do ponto de vista de personagens ex-cêntricos (cf. HUTCHEON, 1991) e de um narrador que ironiza e problematiza o poder da palavra de que lança mão, como em Memorial do convento (1982) ou O ano da morte de Ricardo Reis (1984). Em Claraboia, o discurso engajado é apenas sugerido como um futuro possível a Abel, consciente, ao final, de que "o dia em que será possível construir sobre o amor não chegou ainda..." (SARAMAGO, 2011, p. 377). A escada que uniria todos os apartamentos e todas as vidas, como em Suor, ainda não será construída, mas a tomada de consciência é irremediável.

Abel é, portanto, um precursor dos heróis seguintes de Saramago. Um trajeto semelhante rumo ao engajamento será desenvolvido por H., protagonista de Manual de pintura e caligrafia (1977). Pintor retratista em crise com sua profissão, $H$. investiga novas formas de se expressar, primeiro através da pintura, depois através da escrita, o que resulta numa série de tentativas: a cópia de Dafoe, Rousseau e Yourcenar e os subsequentes exercícios de autobiografia em forma de capítulos de livros. O flerte com diferentes gêneros - a memória, o romance, a confissão, a narrativa de viagem - dá forma ao livro que temos em mãos, "papéis" e "coisas escritas" (SARAMAGO, 1992, p. 277), que repercutem o processo de crescimento - ou de um metafórico "nascimento" desse novo homem, saído de um estado de acídia para, junto com o amor e através dessas tentativas de (auto) expressão, alcançar uma nova atitude frente ao mundo, de engajamento: "A necessidade de agir na história, no seu tempo, ainda que como coadjuvante, vem associada, no romance, à conquista do amor verdadeiro" (GOBBI, 2011, p. 135). Esse movimento entre a inação inicial e a tomada de consciência social é um dos conflitos essenciais dos personagens de José Saramago. Nas palavras de Horácio Costa, a propósito da História do cerco de Lisboa:

À imagem de H., o personagem Raimundo também experimenta, ao longo do romance, aceder a uma nova vida trocando de sinal em plena madurez, passando da acídia à ação, da solidão lata ou compartilhada ao relacionamento amoroso profundo, numa palavra: da infelicidade à alegria. (COSTA, 1997, p. 306)
O desfecho do Manual é bastante significativo neste sentido: aconteceu a Revolução dos Cravos; H. abraça-se a $\mathrm{M}$. e observa pela janela a cidade e a iminência de um novo dia - "oh, cidade, ainda noite por cima das nossas cabeças, mas já uma claridade difusa ao longe" (SARAMAGO, 1992, p. 277). Tal cena espelha outra imagem, retomada em mais de um momento durante o romance, a da contemplação do deserto:

Insisto que tudo é biografia. Tudo é vida vivida, pintada, escrita: o estar vivendo, o estar pintando, o estar escrevendo: o ter vivido, o ter escrevido, o ter pintado. E antes de tudo isto, o mundo ainda era deserto, esperando ou preparando a vinda do homem e dos outros animais, todos os animais, as aves de carne macia, e penas, e cantos. Um enorme silêncio sobre as montanhas e as planícies. E depois, muito mais tarde, o mesmo silêncio, sobre montanhas e planícies já diferentes, e também sobre as cidades vazias, algum tempo ainda com papéis soltos rolados pelas ruas por um vento interrogativo que sai para o campo sem resposta. Entre as duas imaginações, a que $\mathrm{o}$ antes requer e a que depois ameaça, está a biografia, o homem, o livro, o quadro. (...) É preciso imaginar o deserto, olhar o deserto, como o fez naquele filme o Lawrence da Arábia, despovoar tudo, criar o silêncio perfeito, aquele que só os rumores do nosso corpo habitam (...). E agora sim. Agora pode o dia começar a nascer, devagar (...). É preciso apanhar o primeiro relance de luz, a primeira franja, talvez outra vez um pássaro, o lugar da montanha onde o céu assenta, um rosto, um olhar, um sorriso, duas mãos preparadas para construir. (SARAMAGO, 1992, p. 132-133)

O deserto como um lugar, mas também como um tempo, anterior ao texto, anterior à escrita autobiográfica e à autorreflexão. O "tempo de deserto" (SARAMAGO, 1992, p. 153) repercute em uma aridez íntima: "Seremos nós o deserto, ou deixam-nos desertos? Abandonados, deixados, desistidos, ou despovoadores nós e fabricantes do ermo?" (SARAMAGO, 1992, p. 156). A palavra, sempre autobiográfica, e ainda que provisória, funda a ação:

Abordei a consciência disto quando comecei a escrever: todo o meu esforço consistiu, afinal, em recuperar o deserto, para (tentar) compreender depois aquilo que ficasse, aquilo que ficou, aquilo que ficar. A solidão, decerto, mas talvez não a esterilidade. Desabitado, convenho, mas não inabitável. Seco, mas com água dentro, terrível água de lágrimas, frescura possível sobre as mãos, $\mathrm{H}^{2} \mathrm{O}$. A água primordial e o que nela se suspende. (SARAMAGO, 1992, p. 156-157).

Daí o ganho estético do Manual em relação à Claraboia, já que aquele desenvolve o que este apenas 
sugere: a investigação, por parte de $\mathrm{H}$. e do próprio Saramago, de uma forma de expressão adequada aos seus imperativos ideológicos, investigação que repercute formalmente no romance. A construção de um novo homem só se dá através da experimentação da linguagem, na medida em que esse sujeito, nas palavras de Ana Paula Arnaut, "não só se re-conhece pela escrita (...), mas, essencialmente (...), se faz pela(s) linguagem(ns)escrita(s) e pelo progressivo controlo que sobre suas técnicas e os seus segredos vai exercendo" (ARNAUT, 2002, p. 161).

Se para Abel - que vive os anos escuros do salazarismo - a antevista mudança ainda está distante, para H. - que assiste à queda do regime -, ela está às portas. A experimentação de seu Manual é também a de Saramago, que consolidaria seu estilo particular a partir de Levantado do chão, em que a realidade de uma utopia coletiva se desenha em traços mais fortes.

Abel ainda vive o tempo de deserto do salazarismo. Como bem indicou Inês Pedrosa em uma das primeiras resenhas sobre o romance, Claraboia não trata de política senão indiretamente, presente apenas como uma sugestão, que parece cercar os personagens, mas que nunca se mostra efetivamente (cf. PEDROSA, 2011). Isso não significa, porém, que não possamos interpretar o estado de acídia de Abel e de paralisia das famílias desse sobrado, lugar em que o tempo se congela, e "o silêncio era a regra e a palavra a exceção" (SARAMAGO, 2011, p. 163), como uma metáfora de uma época em que, estando a palavra interdita, o prazer não se alcança senão nos instintos mais primitivos, e o cotidiano não passa de uma rotina de sobrevivência desumanizadora.

Ainda preso aos moldes neorrealistas, e com resquícios evidentes de sua herança naturalista, em Claraboia, Saramago é, como H., um retratista, ainda longe de se tornar o narrador arrojado, em exame de suas formas de expressão, de Manual de pintura e caligrafia. $\mathrm{O}$ que não compromete o interesse deste romance, cuja leitura parece completar, como a peça faltante de um mosaico, o período de formação de uma obra indispensável.

\section{Referências}

ABDALA JR., Benjamin. Literatura, história e política: literaturas de língua portuguesa no século XX. Cotia, SP: Ateliê Editorial, 2007.
AMADO, Jorge. O país do carnaval - cacau - suor. São Paulo: Livraria Martins Fontes Editora, 1971

AMADO, Jorge. Suor. São Paulo: Companhia das Letras, 2011.

ARNAUT, Ana Paula. Post-modernismo no romance português contemporâneo: fios de Ariadne, máscaras de Proteu. Coimbra: Almedina, 2002.

AZEVEDO, Aluísio de. O cortiço. Apresentação Paulo Franchetti; notas Leila Guenther. Cotia, SP: Ateliê Editorial, 2012.

BERGAMO, Edvaldo. Ficção e convicção: Jorge Amado e o neo-realismo literário português. São Paulo: UNESP, 2008.

CANDIDO, Antonio. De cortiço a cortiço. Novos Estudos CEBRAP, n. 30, p. 111-119, jul. 2001.

CANDIDO, Antonio. Direito à literatura. In: Vários escritos. Rio de Janeiro: Ouro sobre azul, 2004.

COSTA, Horácio. José Saramago: o período formativo. Lisboa: Caminho, 1997.

DUARTE, Eduardo de Assis. Jorge Amado: romance em tempo de utopia. Rio de Janeiro: Record; Natal, RN: UFRN, 1996.

GOBBI, Márcia Valéria Zamboni. Manual de pintura e caligrafia e a construção do espaço da escrita. In: RAPUCCI, Cleide Antonia; CARLOS, Ana Maria (Org.). Cultura e representação - ensaios. Assis, SP: Triunfal Gráfica e Editora, 2011.

HUTCHEON, Linda. A poética do pós-modernismo. Tradução de Ricardo Cruz. Rio de Janeiro: Imago, 1991.

LOPES, João Marques. Saramago: biografia. São Paulo: Leya, 2010 .

NAMORA, Fernando. A casa da malta. Lisboa: EuropaAmérica, 1998.

PEDROSA, Inês. Maturidade em plena juventude. O Estado de S. Paulo, 15 out. 2011. Disponível em: <http://www. estadao.com.br/noticias/impresso, ${ }^{* * * *}$-claraboia-ineditode-jose-saramago-escrito-aos-30-anos-chega-segunda-aslivrarias-de-portugal-aqui-em-novembro--maturidade-em--plena-juventude-****--,785674,0.htm>. Acesso em: 27 jun. 2013.

SARAMAGO, José. $O$ ano da morte de Ricardo Reis. São Paulo: Companhia das Letras, 2006.

SARAMAGO, José. Claraboia. São Paulo: Companhia das Letras, 2011.

SARAMAGO, José. História do cerco de Lisboa. São Paulo: Companhia das Letras, 2002.

SARAMAGO, José. Manual de pintura e caligrafia. São Paulo: Companhia das Letras, 1992. 